\title{
Shareholder Value Index for Saudi Banks
}

\author{
Sunitha Kumaran ${ }^{1}$ \\ ${ }^{1}$ Department of Finance and Banking, College of Business Administration, Dar Al Uloom University, Saudi Arabia \\ Correspondence: Dr. Sunitha Kumaran, Assistant Professor, Department of Finance and Banking, College of \\ Business Administration, Dar Al Uloom University, Saudi Arabia.
}

Received: April 1, 2017

doi:10.5430/ijfr.v8n4p196
Accepted: April 10, 2017

Online Published: October 17, 2017

URL: https://doi.org/10.5430/ijfr.v8n4p196

\begin{abstract}
This paper aims to examine the shareholder value efficiency and build a Shareholder Value Index for Saudi banks between 2010 and 2014. Shareholder value efficiency is measured using value based performance metrics and binary logistic regression model was adopted to develop the Shareholder Value Index for Saudi banks. The Shareholder Value Index developed provides the probability of a bank's competence to create/erode shareholders' wealth. The study finds that Economic Value Added (EVA) is the value-based performance metric that comes closer than any other to capture the true Economic Profit and the market performance (Market Value Added) of banks. Positive EVA of most of the commercial banks denote that they are more Shareholder value efficient than Islamic banks. High Market Value Added (MVA) represents a highly positive outlook of the investors on the Saudi banks' performance. Value creation is significantly linked to high Net Operating Profit After Tax and a low cost of capital. The most significant observation is that not all banks with highest capital employed are the highest value creators. The Shareholder Value Index developed indicate that majority of Saudi banks demonstrate a higher probability of shareholder value creation. Few Islamic banks showed a less probability of wealth creation for the period of study and are predicted to improve the shareholder value creation ability through their aggressive strategy in the future.
\end{abstract}

Keywords: shareholder value, bank performance, value based performance, efficiency, Mid -East banks, Islamic banks

\section{Introduction}

Banking Sector in Saudi Arabia has made a significant contribution to the economic development of the Kingdom. Indeed, its performance is now regarded as the barometer of Saudi Arabia's economic health. With an increased role envisaged for the private sector, the contribution of the commercial banks is sure to expand in the future. Banks provide the best exposure to the vigor of the economy. Currently, the Saudi stock market's (TASI) capitalization is \$528bn, equivalent to two thirds of Saudi GDP, making it larger than the Mexican stock market. When compared regionally it is almost the same size as all the other equity markets in the Gulf combined. Opening up the market to Foreign Investors is likely to lead to inclusion into the MSCI emerging market index by mid-2017 (Note 1). Given this scenario, Banks are realizing that accounting based measures are often poor indicators of value creation and are searching for appropriate value based measures of corporate performance. This would in turn improve the valuation process adopted by analysts.

Value based performance assessment can represent the raw material for both intrinsic e.g. excess returns models and relative valuation approaches e.g. standardized Market Value Added (Note 2). This study aims at identifying the performance of some of the key value based indicators in case of listed banks in Saudi Arabia. In particular value based measures like Economic Profit (EP), Economic Value Added (EVA), Market Value Added (MVA), CFROI are computed along with traditional measures like Earnings per Share (EPS), Net Interest Margin (NIM), Return on Equity (ROE), Return on Assets (ROA) to have a detailed view on the evolution of shareholder value creation in the banking industry.

This research attempts to contribute to the increasingly needed theoretical and empirical research efforts and studies on the Saudi banking sector; its influence on and relationship with the bank performance indicators. Hopefully, the results of such efforts can be utilized to guide and rationalize the policies of the financial authorities in general and monetary authorities in particular with regard to the control and regulation of the banking units in order to achieve the optimum social welfare objectives e.g. competition, efficiency and growth of the financial sector in the economy. 
The rest of this article is organized as follows: Section 2 presents a selective literature review of shareholder value metrics, main empirical findings of studies on the determinants of shareholder value maximization and studies on Saudi Banking sector. Section 3 presents the data and methods adopted in the study. Section 4 and its subsections provides the descriptive summary of the sample, shareholder value estimates of banks, results of the binary logistic regression analysis and the Shareholder Value Index for the period of study 2010-2014 and the predicted probability for the next 2 financial years. Section 5 recapitulates the key findings of the study and its outcomes.

\section{Review of Literature}

There are a growing number of studies investigating which performance measure is the most suitable to measure the Shareholder Value Maximization of banks. In these studies, the investigation methods are usually very similar: the "relative information content" of alternative accounting measures was assessed looking at difference in the $\mathrm{R}^{2}$ of regressions where the dependent variable was expressed as share prices or market raw returns or market adjusted returns and the independent variable is an accounting measure. In such models, the accounting measure with the higher $\mathrm{R}^{2}$ was described as being the more value relevant. In Incremental association studies, an accounting measure is usually considered value relevant if the regression coefficient is different from zero and statistically significant. A glimpse of the most relevant studies is presented here:

Uyemura et al., (1996), an important study as it particularly focuses on banking, analyzed the largest 100 U.S. bank holding companies over a period of ten years. By regressing changes in standardized MVA against changes in standardized EVA (defined as EVA divided by capital) and traditional performance measures, EVA was found to have highest correlation with MVA.

O'Byrne (1996) analyzed industrial companies and found the EVA superiority in a two-step analysis. At first, the firm's market value was regressed on EVA and then on NOPAT. The study revealed an adj $\mathrm{R}^{2}$ for EVA of 0.31 and of 0.33 for the NOPAT. In the second step, sets of adjustments were proposed: this step showed an adjusted $\mathrm{R}^{2}$ of 0.56 , which enabled him to conclude that EVA is superior to earnings in explaining firm value.

Biddle et al., (1997 and 1999) analyzed a sample of 6174 firm-years over a period 1984-93 by comparing adjusted $\mathrm{R}^{2}$ obtained regressing stock market adjusted returns against EVA, residual Income, accounting earnings (EBEI), and operating Cash Flow. According to their results, EBEI has the highest adjusted $\mathrm{R}^{2}$ and EVA has a smaller adjusted $\mathrm{R}^{2}$. This result suggest that EVA does not dominate accounting earnings in explaining firm values

Peterson and Peterson (1996) used traditional and innovative measures of performance and compared them with stock returns. According to their findings, traditional measures are not empirically less related to stock returns than EVA measures: as a result, they argue that traditional measures should be not eliminated as a means for evaluating performance.

Lehen and Makhija (1997) examined the degree of correlation between different performance measures and stock market returns; found that correlation coefficients vary from 0.39 and 0.76 . In detail, EVA and MVA are the most highly correlated measure with stock market returns: 0.59 and 0.58 (respectively). The other performance measures have smaller correlations.

Noulas (1999) examined the ROE (Return on equity), ROA (Return on assets) ratios of Greek banks, the ratios of leverage and operating efficiency for the period 1993 - 1998. According to the results, there is no significant difference in the return of equity and asset diachronically. Banks profitability showed no improvement in 1998 as compared to 1993 or 1994. The profitability of banks during the last two years (1997-1998) seemed to increase, though, when compared to that of 1996. The latter year is representative, as few banks and especially the state-controlled ones, in their effort to improve their portfolios and to show reduced accounting profitability, have kept large amounts in the provisions account.

Acheampong and Wetzstein (2001) proposed an innovative type of analysis using parametric methods for estimating productive efficiency, focusing on the food industry. It is interesting to note that Acheampong and Wetzstein (2001, p. 7) concluded that: "the analysis showed that there are no significant differences between traditional and value added measures of performance".

Franco Fiordelisi (2002) focused on the information content of traditional and innovative performance indicators in the light of creating shareholder holder value within the banking industry with specific interest on EVA. It was found that EVA is not superior to other measures in term of relative information content, but there is confirming evidence when considering the incremental contribution provided by its components. 
Halkos and Salamouris (2004) concluded, from their study on Greek banks, that the larger the total assets, the higher the efficiency. Furthermore, a positive relationship between size and efficiency was observed for the European banking industry.

Al-Faraj et al. (2006) investigated the performance of the Saudi commercial banking industry using DEA to evaluate the technical efficiency of Saudi banks for the year 2002 and compared with world mean efficiency scores. Their study revealed that the mean efficiency score of Saudi commercial banks compares very well with the world mean efficiency scores. They recommend that Saudi banks should continue their efforts of adapting new technologies and providing more services in order to sustain competitive advantages as Saudi Arabia continues to deregulate the banking industry.

Fiordelisi (2007) developed a new measure of bank performance (referred to as "shareholder value efficiency"): where a bank with maximum possible Economic Value Added (EVA) was defined as "shareholder value efficient", while Beccalli et al., (2006). Eisenbeis et al. (1999), Chu and Lim (1998) test the relationship between stock returns (dependent variable) and various efficiency measures, derived a positive link between return and improvements in efficiency.

Franco Fiordelisi (2010) examined the determinants of shareholder value creation for a large sample of European listed and unlisted banks between 1998 and 2005. Dynamic panel data model was adopted where the bank's shareholder value is a linear function of various bank-specific, industry-specific and macroeconomic variables. Shareholder value and economic profits are found to be negatively related to cost and revenue efficiency and positively linked to bank's leverage. These results are robust to a variety of different model specifications.

Arif Almazari, Abdelkarim Almumani (2012) measured the profitability efficiency of the Saudi national banks for the period 2006-2010 using financial variables and ratios. Multiple Regression was used to test the effect of independent variables on ROA and Operating income (OI), it was found that independent variables affect ROA and it does not affect Operating income (OI). It was also found that banks with higher total assets do not always mean that it has better profitability efficiency.

Munteanu Ancaa, Brezeanu Petre (2012) note that value based performance assessment can represent the raw material for both intrinsic e.g. excess returns models and relative valuation approaches e.g. standardized Market Value Added. The study aimed to measure the shareholder value creation of Romanian listed banks adopted value based measures like Residual Income (RI) and Market Value Added (MVA) but also traditional measures like Earnings per Share (EPS) and Price to Earnings ratio (PER) in order to have a detailed view on the evolution of shareholder value creation in the banking industry.

Nemanja Radic (2014) examined the shareholder value efficiency and its determinants for a large sample of Japanese banks between 1999 and 2011. A new, specifically tailored measure of the Economic Value Added approach, based on the shadow price of equity, was developed in order to account for specific characteristics of the Japanese banking system. The study finds that cost efficiency gains, credit risk and bank size are the most important factors in explaining the shareholder value creation in Japanese banking. Cost efficiency changes are also found to significantly influence cost of equity capital.

Khalid Hamad Alturki (2014) compared the performance of Islamic banks and commercial banks in Saudi Arabia by examining macroeconomic environment factors that affect the banks' performance. The outcomes of the study suggest that low cost, high capital adequacy and low inflation rates contributed to the performance of Saudi banks.

A large number of research papers focus on bank profits by analyzing the impact of a wide range of factors (bank-specific, industry-specific and macroeconomic). However, the notion of "profitability" (usually measured by the Return on Assets - ROA and Return on Equity - ROE) is insufficient to assess bank stability since it does not consider the level of risk-taken. Specifically, the interpretation of high profitability ratios is ambiguous: it can both be interpreted as a signal of bank soundness or as a consequence of a high-risk taking.

This paper was motivated by all the above considerations. The aim is to extend the literature through examining Saudi banks shareholder value efficiency and the determinants of market performance by offering three important contributions. First, in this study efficiency of Saudi banks is measured using a set of traditional financial measures and shareholder efficiency of banks using shareholder value metrics such as EVA (Note 3), MVA (Note 4), CFROI (Note 5 ) and NETCFROI. The use of innovative shareholder value metrics to measure bank efficiency makes an important contribution, since most studies that examine bank efficiency in Saudi Arabia are based on traditional metrics.

Secondly, the study analyses the internal and shareholder value measures to determine the best metric that reflect the market performance of banks. Thirdly, the shareholder value index for listed Saudi banks was developed using Binary 
Logistic Regression Model. The model directly estimates the probability of an event occurring i.e. whether a bank creates/erodes shareholder' wealth.

Lastly, the study contributes to the existing banking literature on Saudi banks and the shareholder value creation ability by focusing on an interesting period 2010-2014 were the Saudi financial system has gone through significant regulatory developments and continued to strengthen in recent years.

\section{Empirical Approach}

\subsection{Data}

The data used in the empirical analysis was drawn from the Tadawul data base, Wharton database, Guru focus and on line resources. In Saudi Arabia, there are 23 banks, of which 12 banks are national and 11 banks are foreign. Out of the 12 national banks, there are only 4 Islamic banks and the remaining are commercial banks. The study focus on all the 12 listed banks between 2010 and 2014.

\subsection{Research Variables}

In this study, Economic Value Added (EVA), Operational profit (OP), Non Performing Loans (NPL), Earnings Per Share (EPS), Net Interest Margin (NIM), Return on Equity (ROE), Return on Assets (ROA) are independent variables while Market Value Added (MVA) is the dependent variable. In order to investigate the determinants of Market Value Added and build a shareholder value index for banks in Saudi Arabia a linear model of bank performance is defined, as is found in the established empirical literature on the determinants of bank performance. The present study adopts the normalizing procedure as suggested by Uyemura (1996) to overcome the effect of asset size. Hence, the metrics are 'standardized' as a percent of capital employed.

A detailed summary of the all variables used for the empirical investigation is provided in Table 1. As defined by Fiordelisi et al (2010), a common measure of shareholder value creation is Economic Value Added (EVA), defined in the present study as the surplus value created by a bank on its existing investments. EVA is calculated as the difference between an "economic measure" of the bank net operating profits after taxes (NOPAT) and a capital charge over the same period, i.e. the product of invested capital and the estimated cost of capital.

Table 1. Descriptive list of variables

\begin{tabular}{ll}
\hline \multicolumn{1}{c}{ VARIABLES } & \multicolumn{1}{c}{ DESCRIPTION } \\
\hline Standardized Economic Value Added & $\begin{array}{l}\text { represents the difference between net operating profits and a capital charge } \\
\text { over the same period /capital employed }\end{array}$ \\
\hline Standardized Market Value Added & fair value of the business's entire debt and equity /capital employed \\
\hline Net operating profit & Net Operating profits \\
\hline Credit risk & $\begin{array}{l}\text { NPL ratio non performing loans are calculated as: (risk-monitored loans }+ \\
\text { loans to borrowers in legal bankruptcy + past due loans in arrears by } 6 \\
\text { months or more + restructured loans + bankrupt and quasi-bankrupt assets }+ \\
\text { doubtful assets + substandard loans)/total assets }\end{array}$ \\
\hline Net Interest Margin & $\begin{array}{l}\text { reflects the efficiency of its intermediation process, a lower margin being } \\
\text { indicative of higher efficiency }\end{array}$ \\
\hline Weighted Average Cost of Capital (WACC) & $\begin{array}{l}\text { minimum rate of return on capital required to compensate debt and equity } \\
\text { investors for bearing risk }\end{array}$ \\
\hline Cash Flow Return on Investment (CFROI) & $\begin{array}{l}\text { "real" (i.e., adjusted for the effect of inflation) rate of return measure, which } \\
\text { identifies the relationship between the cash generated by a business relative to } \\
\text { the cash invested in it }\end{array}$ \\
\hline Return on Equity ROE & measures the revenue created with the funds raised from shareholders' equity. \\
\hline Return on Assets ROA & measures the company's ability to generate profits from its assets \\
\hline Shareholder value efficiency & $\begin{array}{l}\text { measure of bank performance where a bank with maximum possible } \\
\text { Economic Value Added (EVA) is defined as "shareholder value efficient" and } \\
\text { vice- versa Fiordelisi (2007) }\end{array}$ \\
\hline Shareholder value index & $\begin{array}{l}\text { reflects the probability of shareholder value creation\& destruction of banks } \\
\text { developed through Binary logistic regression }\end{array}$ \\
\hline
\end{tabular}


Economic profits are estimated by following the procedure proposed by Fiordelisi (2007) that accounts for banking specific features. Bank economic profits are obtained by adjusting accounting net operating profits to deal with various distortions (i.e. adjustments covering loan-loss provisions, loan-loss reserves; general risk reserves; $R \& D$ expenses and operating lease . the cost of equity is based on capital assets pricing model (CAPM).

Stewart $(1990,153)$ state that difference between the company's market and book value as Market Value Added or MVA.

CFROI is a "real" (i.e., adjusted for the effect of inflation) rate of return measure, which identifies the relationship between the cash generated by a business relative to the cash invested in it. CFROI represents the "discount rate" that "discounts" the future annual cash flows that are expected to arise over the average life of a firm's assets, back to current cash value (i.e. adjusted for inflation) of the firm's net operating assets.

\subsection{Methodology}

Market Value Added by a bank is defined to have only two outcomes i.e. a bank can either be a Wealth Creator or not. Hence, for an outcome that is a dichotomy, Binary Logistic Regression Analysis could be used. Binary logistic regression model is used to estimate the probability that one of the two events occurs, i.e. either wealth creation or not in a bank based on the values of a set of independent variables or financial metrics.

The only assumptions that are required are that the observations are independent and that the variables are linearly related to the $\log$ of the odds that an event occurs. The data was also tested for linearity, homogeneity and normality before using them in the linear equation model.

In the case of a single independent variable, the Binary logistic regression model is:

$$
\begin{aligned}
\text { Prob }(\text { creating wealth })= & 1 \\
& 1+\mathrm{e}^{-(\mathrm{z})}
\end{aligned}
$$

$\mathrm{z}$ is the linear combination

$$
\begin{aligned}
& \mathrm{Z}=\mathrm{b}_{0}+\mathrm{b}_{1} \mathrm{X}_{1}+\mathrm{b}_{2} \mathrm{X}_{2} \\
& =1 \\
& 1+\mathrm{e}^{-(-\mathrm{bo}+\mathrm{b} 1 \mathrm{X})}
\end{aligned}
$$

Where $b_{0}$ and $b_{1}$ are coefficients, $X$ is the independent variable; e is the base of the natural logarithms, approximately 2.718. The probability estimate is always between 0 and 1 regardless of the value of $Z$.

Null hypothesis, that

$\mathrm{H}_{0}$ : "The coefficient of all the financial metrics in the binary logistic regression for listed banks is zero". was tested using Binary Logistic Regression Model.

\section{Empirical Results \& Inference}

\subsection{Financial Performance of Banks}

Profitability indicators in Tables $2 \& 3$ demonstrate that commercial banks have maintained more sustainable and steady growth rates than Islamic banks. It is observed that banks such as Alrajhi, National Commercial Bank (NCB), SAMBA recorded the highest Net Income (NI) whereas Albilad, Alinma, Aljazaria showed the lowest NI during the period of study. NCB, Alrajhi, Riyad bank had deployed the highest assets into their operations, while Albilad, Alinma, Aljazaria, Saudi investment bank (SIB) had invested the lowest assets in banking operations. Alrajhi, NCB, SAMBA, SIB records the highest ROE \& ROA and banks such as Aljazaria, Alinma fall in the lowest. 
Table 2. Descriptive statistics for all the banks *

\begin{tabular}{lrrrrr}
\hline & $\mathrm{N}^{*}$ & \multicolumn{1}{c}{ Minimum } & \multicolumn{1}{c}{ Maximum } & \multicolumn{1}{c}{ Mean } & Std. Deviation \\
\hline NIOPERATIONS & 12 & 411087.20 & 7261626.60 & 2876422.6667 & 2337596.31552 \\
TA & 12 & 32034915.60 & 348209740.80 & 142852826.950 & 95496016.0732 \\
& & & 0 & 5 \\
ROE & 12 & .0416 & .2132 & .126482 & .0472608 \\
ROA & 12 & .0101 & .0317 & .019819 & .0053862 \\
NIM & 12 & .0226 & .0389 & .027711 & .0054350 \\
NPL & 12 & .0034 & .0367 & .021283 & .0096870 \\
EPS & 12 & .4640 & 4.5350 & 2.157750 & 1.1874700 \\
COVRATIO & 12 & .89 & 2.09 & 1.6192 & .29928 \\
Valid N (listwise) & 12 & & & & \\
\hline
\end{tabular}

* Includes both commercial and Islamic banks in Saudi Arabia

Table 3. Group-wise statistics of banks

\begin{tabular}{|c|c|c|c|}
\hline & Minimum & $\underline{\text { Maximum }}$ & $\underline{\text { Mean }}$ \\
\hline \multicolumn{4}{|c|}{ COMMERCIAL BANKS** } \\
\hline NI* & 954458 & 6754981 & 3195400 \\
\hline $\mathrm{TA}^{*}$ & 67325064 & 348209741 & 165994073 \\
\hline ROE & 10.06 & 18.80 & 14.47 \\
\hline ROA & 0.01 & 0.02 & 0.019 \\
\hline NIM & 0.02 & 0.03 & 0.025 \\
\hline NPL & 1.17 & 3.07 & 2.046 \\
\hline EPS & 1.18 & 4.14 & 2.27 \\
\hline COVRATIO & 0.89 & 2.09 & 1.57 \\
\hline \multicolumn{4}{|c|}{ ISLAMIC BANKS $* * * *$} \\
\hline $\mathrm{NI}^{*}$ & 411087 & 7261627 & 2238469 \\
\hline TA* & 49880666 & 252123825 & 96570334 \\
\hline ROE & 4.16 & 21.32 & 12.31 \\
\hline ROA & 0.01 & 0.03 & 0.020 \\
\hline NIM & 0.03 & 0.04 & 0.034 \\
\hline NPL & 0.42 & 3.67 & 2.31 \\
\hline EPS & 0.46 & 4.54 & 1.93 \\
\hline COVRATIO & 1.53 & 1.96 & 1.71 \\
\hline
\end{tabular}

* in million Saudi riyals

** Riyad Bank (RYB), Saudi Investment Bank (SIB), Saudi Hollandi Bank (SHB), Banque Saudi Fransi (BSF) TheSaudi British Bank (SABB), Arab National Bank (ANB), Samba Financial Group (SAMBA), The National Commercial Bank (NCB)

*** Al Rajhi Bank (RJHI), Bank AlJazira, Bank (BAJ), Bank Al-Bilad (BAB), Alinma Bank (AIB)

Net Interest Margin (NIM) of Islamic banks were the highest, this is mainly accounted by the lower total assets invested by them. On the other hand SAMBA, SAAB, SHB reported the lowest margin. Both groups of banks 
maintained satisfactory level of asset quality as measured by non-performing loans (NPL). However, non-performing loans were highest for Albilad, Aljazaria, NCB, SAMBA and the lowest for Alinma, Alfransi, and Riyad bank etc. Higher NPLs suggest the asset quality of commercial banks remain a concern and indicates banks' aggressiveness in lending. It indicates credit risk of bank. Coverage ratios of NCB, SAMBA, and Aljazaria showed bank's inability to meet its financial obligations. Coverage ratios of Alinma, Albilad, ANB, and SIB were better mainly because of low non-performing loans.

Net profit after taxes as a percent of shareholders' equity of Commercial banks was observed to be higher than Islamic banks. This indicates that Saudi commercial banks efficiently deploy its shareholders' funds. The higher the quality of the loan approval process and better the risk management measures adopted, the lower the non-performing loans and thus the higher the banking operating performance will be. It was observed from the cost estimates that Islamic banks are observed to have higher levels of cost to income than commercial banks. These results can be explained as the commercial banks have a higher lending margins, high net incomes from associates or volatile trading income than Islamic banks.

Overall, it was observed that Islamic banks in Saudi Arabia with the exception of Alrajhi bank recorded a weak performance compared to commercial banks between 2010-2014.

\subsection{Shareholder Value Efficiency of Banks}

Table 4 presents the summary of input variables computed to determine the shareholder value efficiency of banks. Shareholder value efficiency of a bank is dependent on the cash flow generating capability of banks, profitability and ability to reduce the cost of capital for the bank.

Table 4. Summary of input variables for Saudi banks

\begin{tabular}{lrrrrr}
\hline & $\mathrm{N}$ & \multicolumn{1}{c}{ Minimum } & Maximum & \multicolumn{1}{c}{ Mean } & Std. Deviation \\
\hline Commerical Banks & & & & & \\
NETCASHFLOW & 8 & 1021036.20 & 7371334.60 & 3397031.7750 & 2003319.08190 \\
COSTOFEQUITY & 8 & .08 & .14 & .0909 & .02070 \\
WACC & 8 & .02 & .03 & .0246 & .00326 \\
Valid N (listwise) & 8 & & & & \\
\hline Islamic Banks & & & & & \\
NETCASHFLOW & 4 & 483959.60 & 7656783.20 & 2412767.8000 & 3498805.38551 \\
COSTOFEQUITY & 4 & .10 & .12 & .1095 & .01158 \\
WACC & 4 & .03 & .04 & .0312 & .00832 \\
Valid N (listwise) & 4 & & & & \\
\hline All banks & & & & & \\
NETCASHFLOW & 12 & 483959.60 & 7656783.20 & 3068943.7833 & 2475357.28020 \\
COSTOFEQUITY & 12 & .08 & .14 & .0971 & .01984 \\
WACC & 12 & .02 & .04 & .0268 & .00602 \\
Valid N (listwise) & 12 & & & & \\
\hline
\end{tabular}

Cost of equity of banks computed across the period of study varies between $8 \%-14 \%$. Cost of equity for Islamic banks is higher than the commercial banks. Being relatively a new banking model in the market, investors fail to comprehend the risk inherent in their instruments. Moreover Islamic banks face risk that are similar to traditional financial intermediaries, unique risk that rise owing to its compliance with the sharia'a and restricted use of risk mitigation instruments than their counterparts. Under this background investors increase their exposure to risks, hence expect a higher rate of return or cost of equity from Islamic banks. 
It is evident that commercial banks are characterized with higher cash flows than Islamic banks, cost of equity and the weighted average cost of capital lesser than the Islamic banks. Commercial banks booked higher liabilities growth rates compared to their assets over the years, which explain the reason for higher cost of debt funds.

Table 5 presents the summary of value based performance measures used to estimate the shareholder efficiency of banks.

Table 5. Summary of shareholder value estimates of Saudi banks

\begin{tabular}{lrrrrr}
\hline & $\mathrm{N}$ & Minimum & Maximum & \multicolumn{1}{c}{ Mean } & Std. Deviation \\
\hline Commerical Banks & & & & & \\
Standardized MVA* & 8 & .7726 & 28.8937 & 6.279975 & 9.2580880 \\
Standardized EVA** & 8 & .0090 & .4240 & .093625 & .1352595 \\
CFROI & 8 & .0148 & .0232 & .019713 & .0023967 \\
NETCFROI & 8 & -.0100 & .0034 & -.005293 & .0041056 \\
Valid N (listwise) & 8 & & & & \\
\hline Islamic Banks & & & & & \\
Standardized MVA & 4 & 4.4261 & 61.6460 & 22.750326 & 26.3485103 \\
Standardized EVA & 4 & -.7360 & .2690 & -.124000 & .4313058 \\
CFROI & 4 & .0092 & .0313 & .018850 & .0095200 \\
NETCFROI & 4 & -.0293 & .0042 & -.012376 & .0142371 \\
Valid N (listwise) & 4 & & & & \\
\hline All banks & & & & & \\
Standardized MVA & 12 & .7726 & 61.6460 & 11.770092 & 17.5967728 \\
Standardized EVA & 12 & -.7360 & .4240 & .021083 & .2717678 \\
CFROI & 12 & .0092 & .0313 & .019425 & .0053435 \\
NETCFROI & 12 & -.0293 & .0042 & -.007654 & .0088414 \\
Valid N (listwise) & 12 & & & & \\
\hline
\end{tabular}

* Standardized Market Value Added = MVA / capital employed

** Standardized Economic Value Added = EVA / capital employed

As the objective of financial institutions is to create, value for the shareholders by acquiring assets in multiples of shareholder-owned funds, managing the resulting risks faced by the equity becomes an important function of these institutions. Std MVA of Islamic banks is higher than commercial banks. The value is observed to be inflated because of the presence ALRAJHI bank that is the largest and the oldest bank in the Islamic banking sector. The average would drop down $9.79 \mathrm{~m}$ on removing the same from the sample.

Economic profit describes the surplus earned by a business in a period after the deduction of all expenses, including the cost of using investors' capital in the business. Economic value Added as explained by Steward (1991) is effectively a refined version of the basic Economic Profit (EP) approach. PBDT is adjusted to arrive at the adjusted NOPAT. Std EVA of commercial banks is positive and greater than the commercial banks. This is an evidence of the ability of commercial banks to general profit greater than the overall cost of capital. Islamic banks on the other hand records negative economic value added driven by less profit and high cost of capital. The combination of high MVA and negative EVA of Islamic banks, signals that Islamic banks stocks are more traded than commercial bank stocks. Islamic bank stocks turned out to be aggressive with beta $>1$. It is inferred that in Saudi stock market the share prices are driven by market whims rather than financial performance of the banks. Positive EVA of commercial banks denote that they are more Shareholder value efficient than Islamic banks.

CFROI of both commercial and Islamic banks are almost identical. Cash flow return on investment suggests that prices of stocks in the stock markets are set based on cash flows rather than the earning or the performance of a 
business. The net CFROI, of both types of banks are negative. It denotes the inability of both types of banks to generate a Cash Flow Return greater than the cost of capital i.e. the cost to finance the debt and investors' expected return on their investment.

It is observed from Table 6 that in terms of MVA during the period 2010-16, the best market performers were Alrajhi bank, NCB, SIB, Alinma bank and the least performers were Bank Aljazira, Saudi Investment Bank and SAMBA. Islamic banks top the list by being investor's favorite's in spite their poor financial performance. Successful banks have added their MVA and in turn increased the value of capital invested. On the other hand, few banks failed to add value to their investment. For a bank to create MVA (increase shareholder value) or not, depends on its ability to generate rate of return greater than its cost of capital. In this case, their stock sell on the stock markets with premium compared to their counterparts (sell at discount) with rate of return lesser than the cost of capital.

Table 6. Shareholder value estimates of Saudi banks

\begin{tabular}{|c|c|c|c|c|c|c|c|c|c|c|c|c|}
\hline & MVA & MVA & MVA & EVA & EVA & EVA & CF & CF & CF & CFROI & CFROI & CFROI \\
\hline \multicolumn{13}{|l|}{ BANKS / } \\
\hline SAR & 2010- & & & 2010- & & & 2010- & & & 2010- & & \\
\hline millions & 2014 & 2015 & 2016 & 2014 & 2015 & 2016 & 2014 & 2015 & 2016 & 2014 & 2015 & 2016 \\
\hline $\begin{array}{l}\text { Al Rajhi } \\
\text { Bank }\end{array}$ & $4,316,000$ & $4,619,875$ & $4,174,375$ & 3,601 & 14,837 & 5,476 & $7,656,783$ & $7,303,021$ & $7,358,181$ & $3.13 \%$ & $2.09 \%$ & $1.85 \%$ \\
\hline Riyad Bank & 154,200 & 110,396 & 70,738 & 725 & 10,753 & 4,639 & $3,823,107$ & $4,848,582$ & $5,435,260$ & $1.97 \%$ & $2.14 \%$ & $2.28 \%$ \\
\hline $\begin{array}{l}\text { Bank } \\
\text { AlJazira }\end{array}$ & 49,560 & 61,829 & 78,218 & -266 & 2,364 & 654 & 483,960 & 766,445 & 903,928 & $0.92 \%$ & $0.96 \%$ & $0.95 \%$ \\
\hline $\begin{array}{l}\text { Saudi } \\
\text { Investment } \\
\text { Bank }\end{array}$ & 34,200 & 36,135 & 39,352 & 99 & 3,707 & 1,732 & $1,021,036$ & $1,796,018$ & $2,096,021$ & $1.48 \%$ & $1.64 \%$ & $1.64 \%$ \\
\hline $\begin{array}{l}\text { Saudi } \\
\text { Hollandi } \\
\text { Bank }\end{array}$ & 87,731 & 105,858 & 131,855 & 510 & 4,098 & 2,339 & $1,380,483$ & $2,292,959$ & $2,733,837$ & $1.92 \%$ & $2.05 \%$ & $2.11 \%$ \\
\hline $\begin{array}{l}\text { Banque } \\
\text { Saudi } \\
\text { Fransi }\end{array}$ & 112,701 & 85,010 & 69,766 & 990 & 8,061 & 3,492 & $3,057,726$ & $3,935,294$ & $4,253,800$ & $1.99 \%$ & $1.87 \%$ & $1.82 \%$ \\
\hline $\begin{array}{l}\text { The Saudi } \\
\text { British } \\
\text { Bank }\end{array}$ & 215,200 & 226,556 & 247,457 & 1,364 & 9,356 & 4,957 & $3,309,956$ & $4,957,793$ & $5,718,863$ & $2.08 \%$ & $2.39 \%$ & $2.49 \%$ \\
\hline $\begin{array}{l}\text { Arab } \\
\text { National } \\
\text { Bank }\end{array}$ & 99,000 & 89,625 & 87,622 & 818 & 6,289 & 3,060 & $2,558,866$ & $3,371,915$ & $3,712,692$ & $1.90 \%$ & $1.87 \%$ & $1.88 \%$ \\
\hline $\begin{array}{l}\text { Samba } \\
\text { Financial } \\
\text { Group }\end{array}$ & 45,240 & 15,761 & $-15,975$ & 985 & 13,327 & 4,480 & $4,653,746$ & $5,394,988$ & $5,658,916$ & $2.32 \%$ & $2.39 \%$ & $2.42 \%$ \\
\hline $\begin{array}{l}\text { Bank } \\
\text { Al-Bilad }\end{array}$ & 95,600 & 123,590 & 160,554 & 48 & 2,620 & 1,059 & 685,812 & $1,129,718$ & $1,334,264$ & $2.06 \%$ & $2.06 \%$ & $2.00 \%$ \\
\hline $\begin{array}{l}\text { Alinma } \\
\text { Bank }\end{array}$ & 125,250 & 185,979 & 254,298 & $-1,360$ & 6,411 & 1,353 & 824,516 & $1,693,181$ & $2,022,198$ & $1.43 \%$ & $14.32 \%$ & $1.42 \%$ \\
\hline $\begin{array}{l}\text { The } \\
\text { National } \\
\text { Commercial } \\
\text { Bank }\end{array}$ & 646,200 & 603,621 & 587,472 & 4,295 & 17,229 & 10,548 & $7,371,335$ & $\begin{array}{c}10,626,13 \\
2\end{array}$ & $\begin{array}{c}12,365,54 \\
4\end{array}$ & $2.11 \%$ & $2.19 \%$ & $2.29 \%$ \\
\hline
\end{tabular}


Economic Value Added (EVA) measures the shareholder value efficiency of banks. SAMBA bank topped the list of shareholder value efficiency with the highest EVA followed by Alrajhi, Saudi Fransi, and NCB respectively. Banks with the least shareholder value efficiency were Saudi British Bank, Alinma, and Aljazira.

Net Cash flow of Saudi British Bank, SAMBA, Saudi Investment Bank is the highest in the list with Bank AlJazira, Alinma Bank and Banque Saudi Fransi being the lowest. Cash Flow Return on Investment (CFROI) is real rate of return measure (i.e., adjusted for the effect of inflation), which measures the excess cash generated by a business relative to the cash invested in it. The prospective banks with the highest CFROI were Alinma, SAMBA, and Alrajhi respectively.

It is inferred that the competence of Saudi banks in generating shareholder value is certainly high. A higher adjusted Net Operating Profit after tax (NOPAT) and a lower Cost of Capital is found to have the highest significant positive impact on EVA. The results of the study are in line with the research outcomes of Fiordelisi and Molyneux (2010), where results confirm that higher adjusted NOPAT, low cost of capital and bank's assets size are driving the shareholder value. The low correlation between EVA and Capital employed observed in the present study shows that not all banks with the highest capital were the highest shareholder value creators.

It is observed from Chart 1 that Market Value Added (MVA) and Economic Value Added (EVA) by banks have increased over the years. MVA has increased rapidly while EVA definitely signals a positive outlook. Stewart (1990) state that Market Value Added = Present value of all future EVA. Accordingly increase in EVA also increases its MVA and this relationship +/- would have its implications on the banks' valuation. The MVA value on the other hand represents a highly positive outlook of the investors on the Saudi banks' performance.

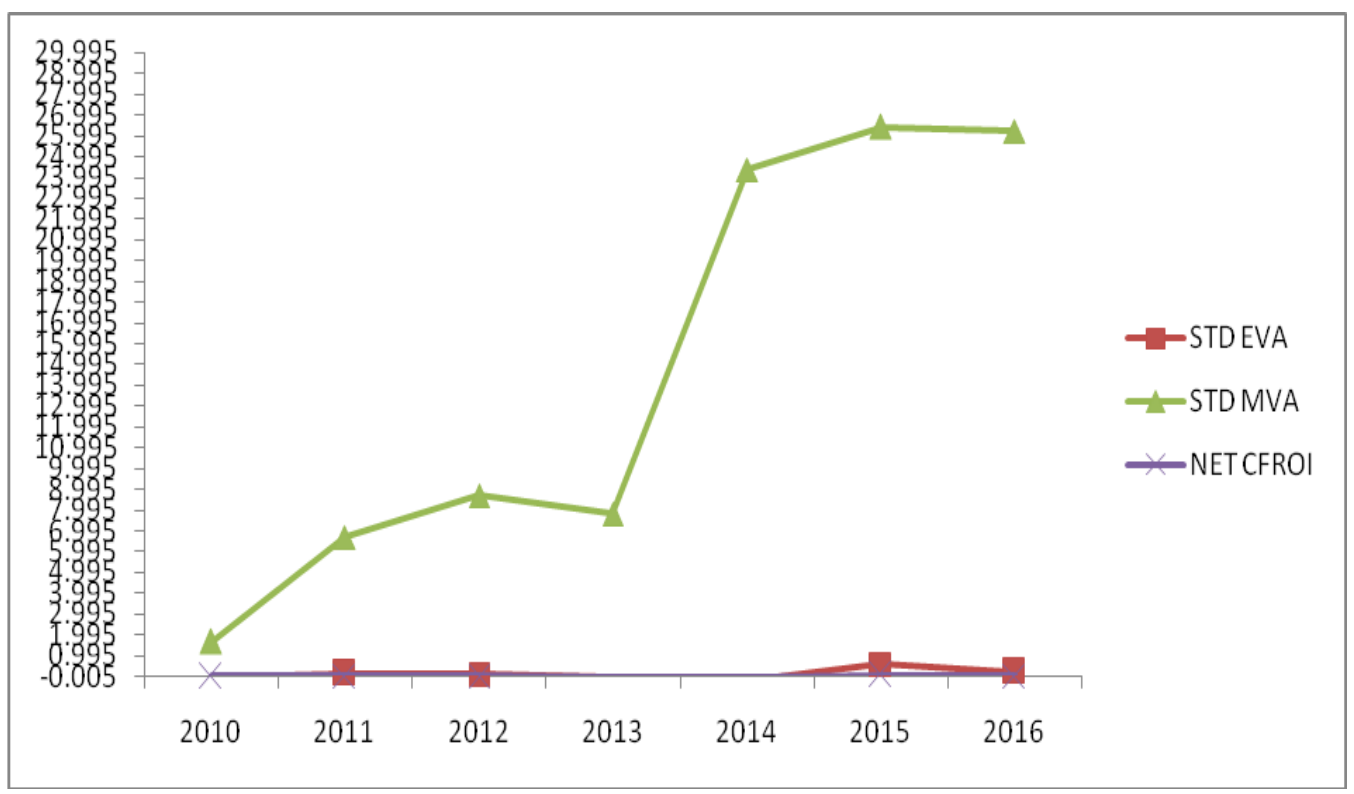

Chart 1. Shareholder efficiency of Saudi banks

\subsection{Shareholder Value Index of Banks}

Managing to create a sustained and sustainable shareholder value is currently recognized as a reasonable goal by regulators. Shareholder Value Addition is measured over a period rather than a particular time. Most of the global stock markets are anything but mature; the Market Value is a highly volatile figure that often does not have any mathematical linkage with the internal performance of the banks or a logical one with the fundamentals of the company. Index generated by various stock exchanges reflects the current market performance of a particular stock, on the other hand fundamental analysis reflects the internal strength of the banks. The Shareholder Value Index developed will add more information than that provided by fundamental analysts. The shareholder value index will provide information on the probability of shareholder value creation/depletion in a bank. 


\subsubsection{Binary Logistic Regression Output}

Binary logistic regression analysis was used to estimate the probability that one of the two events occurs, i.e. either shareholder value created/eroded in a bank based on the values of a set of independent variables or financial metrics. To construct the model, best subset of metrics namely: EVA, ROE, NIM, NPL, EPS and CFROI are taken as independent variables to be regressed against MVA. A summary of the logistic regression output is explained in the following tables.

Table 7. Model summary

\begin{tabular}{lrrr}
\hline Step & $\begin{array}{c}-2 \text { Log } \\
\text { likelihood }\end{array}$ & $\begin{array}{c}\text { Cox \& Snell R } \\
\text { Square }\end{array}$ & $\begin{array}{c}\text { Nagelkerke } \\
\text { R Square }\end{array}$ \\
\hline 1 & $4.519^{\mathrm{a}}$ & .416 & .679 \\
\hline
\end{tabular}

a. Estimation terminated at iteration number 7 because parameter estimates changed by less than .001 .

Table 8. Variables in the equation

\begin{tabular}{|c|c|c|c|c|c|c|c|c|c|}
\hline & & \multirow{2}{*}{ B } & \multirow{2}{*}{ S.E. } & \multirow{2}{*}{ Wald } & \multirow{2}{*}{ df } & \multirow{2}{*}{ Sig. } & \multirow{2}{*}{$\operatorname{Exp}(B)$} & \multicolumn{2}{|c|}{ 95\% C.I.for EXP(B) } \\
\hline & & & & & & & & Lower & Upper \\
\hline Step & EVA & -8.633 & 6.953 & 1.542 & 1 & .014 & .000 & .000 & 5.349 \\
\hline $1^{\mathrm{a}}$ & Constant & -1.742 & 1.006 & 2.999 & 1 & .092 & .083 & & \\
\hline
\end{tabular}

a. Variable(s) entered on step 1: EVA.

b. other variables ROE,NIM,NPL,EPS,CFROI are all excluded from the model

Forward stepwise regression method used in the process starts with a model that does not include any of the predictors. At each step, the predictor with the largest score statistic whose significance value is less than a specified value (by default 0.05 ) is added to the model. The variables left out of the analysis at the last all have significance values larger than 0.05 , so no more are added. From the output of forward stepwise regression reported in Tables $7 \&$ 8 , it is evident that EVA is the only variable chosen to have a significant impact on dependent variable MVA, while all other variables are insignificant hence removed from the regression model. It is observed from Tables 7 \& 8 that the variable EVA chosen by the forward stepwise method have significant changes in -2 Log Likelihood. In the linear regression model, the coefficient of determination $\mathrm{R}^{2}$, summarizes the proportion of variance in the dependent variable associated with the predictor (independent) variables.

Table 7 provides the Pseudo R square statistics. There are two measures, Cox \& Snell and Nagelkerke. In this case Cox \& Snell is 0.416, and Nagelkerke is 0.679. These numbers indicate that Economic Value Added (EVA) could explain $42 \%$ of the variation in a bank's ability to create or destroy wealth of shareholders.

Table 9. Omnibus tests of model coefficients

\begin{tabular}{lllll}
\hline & & Chi-square & df & \multicolumn{2}{c}{ Sig. } \\
\hline \multirow{3}{*}{ Step 1 } & Step & 5.912 & 1 & .015 \\
\cline { 2 - 5 } & Block & 5.912 & 1 & .015 \\
\cline { 2 - 5 } & Model & 5.912 & 1 & .015 \\
\hline
\end{tabular}

The chi-square Table 9 shows that the variable EVA added into the model shows a significant change. The difference in the -2LL for the complete model and -2LL for the constant only model is 5.912, which is the chi-square value shown in Table 9. There exists a significant difference in the coefficients for the complete model and the constant only model. Based on the observed significant level shown, the hypothesis that:

$\mathrm{H}_{0}$ : "The coefficient of all the financial metrics in the binary logistic regression for listed banks is zero"

Tested using Binary Logistic Regression Model is rejected and the alternate hypothesis that coefficient of not all financial metrics is zero in listed banks is accepted. 
Table 10. Hosmer and Lemeshow Test

\begin{tabular}{lcccr}
\hline Step & Chi-square & df & \multicolumn{2}{c}{ Sig. } \\
\hline 1 & 3.434 & & 8 & .904 \\
\hline
\end{tabular}

Goodness of fit statistics is provided in Table 10. The output of the test was used to determine whether the model adequately describes the data. Hosmer-Lemeshow statistic demonstrates that the significance value is greater than 0.05 , hence the model adequately fits the data.

Table 11. Variables in the equation

\begin{tabular}{|c|c|c|c|c|c|c|c|c|c|}
\hline & & \multirow[t]{2}{*}{$\mathrm{B}$} & \multirow[t]{2}{*}{ S.E. } & \multirow{2}{*}{\multicolumn{3}{|c|}{ Wald df Sig. }} & \multirow[t]{2}{*}{$\operatorname{Exp}(B)$} & \multicolumn{2}{|c|}{ 95\% C.I.for EXP(B) } \\
\hline & & & & & & & & Lower & Upper \\
\hline \multirow{2}{*}{ Step $1^{\mathrm{a}}$} & EVA & -8.633 & 6.953 & 1.542 & 1 & .014 & .000 & .000 & 5.349 \\
\hline & Constant & -1.742 & 1.006 & 2.999 & 1 & .092 & .083 & & \\
\hline
\end{tabular}

The value 'B' in Table 11 refers to the log-odds of a bank being destroyer of shareholders wealth. The values indicates that decreasing EVA increases the log-odds of a bank being destroyer of shareholders wealth whereas increasing EVA decreases the log-odds of a bank being destroyer of shareholders wealth. The logistic regression equation developed using this output (Note 6) is:

$$
\begin{aligned}
\operatorname{logit}(\pi) & =\alpha+\beta_{1} X_{1}+\beta_{2} X_{2} \ldots \ldots \ldots \ldots+\beta_{n} X_{n} \\
& =-1.742+-8.633(\text { EVA) }
\end{aligned}
$$

It is evident from equation ...... that a decrease in EVA increases the log odds of shareholders wealth being depleted controlling for number of years of establishment, adoption of Islamic banking practices or not, number of services being extended and nature of bank. The significance of the Wald statistic reported shows that the predictor variable is significant.

The results observed are well aligned with the observation made by Stern (1990) that Economic Value Added is the best financial performance measure that captures the true Economic Profit of a bank. EVA based financial management and incentive compensation system gives manager superior information and superior motivation to make decisions that will create greater shareholder value. A bank's EVA is the fuel that fires up its Market Value Added. International financial management practices reveal that three ways to increase EVA according to experts are: 1) earn more profit without using more capital 2) use less capital 3) invest capital in high return projects.

Table 12. Classification Table ${ }^{\mathrm{a}, \mathrm{b}}$

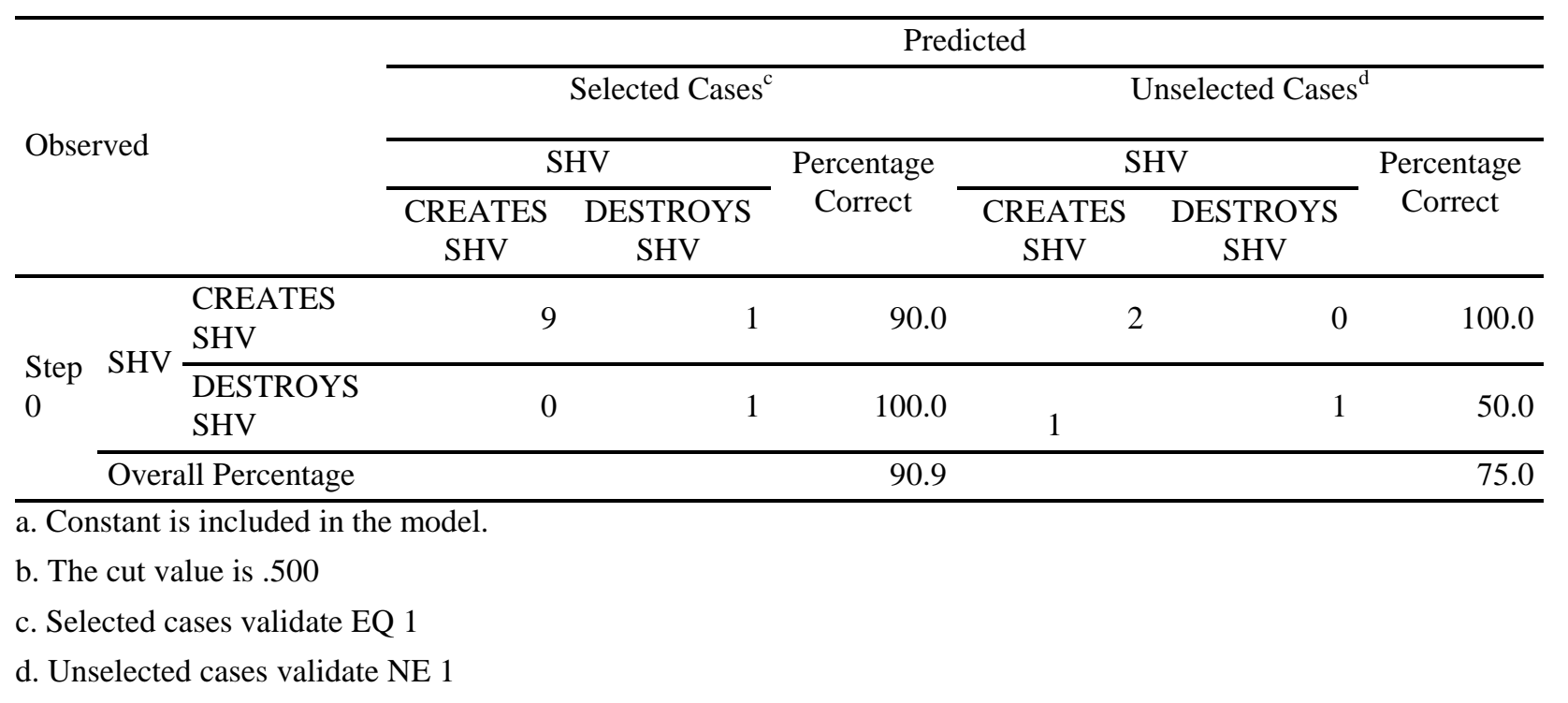


Classification given in Table 12: explains that of the 15 cases used to create the model (with three proxy banks) (Note7), the only bank which has previously destroyed shareholders wealth has been classified correctly. Similarly, out of 10 banks that have created shareholders' wealth, 9 banks are classified correctly. Overall $90.9 \%$ of the cases are classified correctly. Subset validation is obtained by classifying past banks which were not used to create the model. The results in the unselected cases section shows that $75 \%$ of these banks were correctly classified.

\subsubsection{Shareholder Value Index for Listed Banks}

The probability of share value creation/erosion by banks was developed using the output of binary logistic regression model in eq. 1 (Note 8). Table 13 presents the 5-year average shareholder value index developed for Saudi banks. The shareholder value index developed is purely a fundamental measure. An investment based on probability of share value creation/erosion held by banks is the best and safest. Shareholder value index remains unaffected by the market and is unbiased.

It is observed that the big shareholder value creators were banks such as NCB, Alrajhi, SABB, Saudi Hollandi Bank ..; on the other hand the least value creators are Alinma and Aljazira. Both commercial banks and Islamic banks are competent in shareholder value addition. The largest shareholder value creators are observed to have high capital employed, high net income, high ROE and ROA, low NPL ratio and high EPS. Alinma bank faced few setbacks during 2011-2014 in the form of less capital deployment, less net income gained, least ROA \&ROE, low NPL ratio and less EPS. Low NPL ratio signifies either good quality loans or less aggressive in lending.

Table 13. Shareholder value index for Saudi banks between 2010-2014

\begin{tabular}{|c|c|c|}
\hline BANKS & $\begin{array}{l}\text { Probability } \\
\text { of shareholder value creation }\end{array}$ & $\begin{array}{c}\text { Probability } \\
\text { of shareholder value erosion }\end{array}$ \\
\hline Alrajhi Bank & 0.98 & 0.02 \\
\hline Riyad Bank & 0.87 & 0.13 \\
\hline Bank Aljazira & 0.77 & 0.23 \\
\hline Saudi Investment Bank & 0.86 & 0.14 \\
\hline Saudi Hollandi Bank & 0.91 & 0.09 \\
\hline Banque Saudi Fransi & 0.90 & 0.10 \\
\hline The Saudi British Bank & 0.91 & 0.09 \\
\hline Arab National Bank & 0.90 & 0.10 \\
\hline Samba Financial Group & 0.89 & 0.11 \\
\hline Bank Al-Bilad & 0.89 & 0.11 \\
\hline Alinma Bank & 0.01 & 0.99 \\
\hline The National Commercial Bank & 1.00 & 0.00 \\
\hline
\end{tabular}


The predicted probability of value creation/erosion for the year 2015 is given in Table 14. It is observed that all Saudi banks demonstrate an increase in their ability of shareholder value creation/erosion. Alinma bank demonstrated a turnover to become shareholder value creator in 2015. A detailed look into the financial metrics of the bank showed that the net capital employed has increased and the bank has started to adopt an aggressive strategy to improve the profitability and efficiency ratios. Another Islamic bank Aljazira has also increased its ability to add value to shareholders' investment.

Table 14. Shareholder value index for Saudi banks for the year 2015

\begin{tabular}{lcc}
\hline \multicolumn{1}{c}{ BANKS } & $\begin{array}{c}\text { Probability } \\
\text { of shareholder value } \\
\text { creation }\end{array}$ & $\begin{array}{c}\text { Probability } \\
\text { of shareholder value } \\
\text { erosion }\end{array}$ \\
\hline Alrajhi Bank & 0.99 & 0.01 \\
\hline Riyad Bank & 0.91 & 0.09 \\
\hline Bank Aljazira & 0.86 & 0.14 \\
\hline Saudi Investment Bank & 0.90 & 0.10 \\
\hline Saudi Hollandi Bank & 0.94 & 0.06 \\
\hline Banque Saudi Fransi & 0.93 & 0.07 \\
\hline The Saudi British Bank & 0.94 & 0.06 \\
\hline Arab National Bank & 0.93 & 0.07 \\
\hline Samba Financial Group & 0.93 & 0.07 \\
\hline Bank Al-Bilad & 0.94 & 0.06 \\
\hline Alinma Bank & 0.51 & 0.49 \\
\hline The National Commercial Bank & 0.99 & 0.01 \\
\hline
\end{tabular}

The predicted probability in Table 15 shows that Saudi banks will be shareholder value creators in the year 2016 . Alinma bank again demonstrates an ability to improve the shareholder wealth created.

Table 15. Shareholder value index for Saudi banks for the year 2016

\begin{tabular}{lcc}
\hline \multicolumn{1}{c}{ BANKS } & $\begin{array}{c}\text { Probability } \\
\text { of shareholder value creation }\end{array}$ & $\begin{array}{c}\text { Probability } \\
\text { of shareholder value erosion }\end{array}$ \\
\hline Alrajhi Bank & 0.98 & 0.02 \\
\hline Riyad Bank & 0.92 & 0.08 \\
\hline Bank Aljazira & 0.88 & 0.12 \\
\hline Saudi Investment Bank & 0.91 & 0.09 \\
\hline Saudi Hollandi Bank & 0.95 & 0.05 \\
\hline Banque Saudi Fransi & 0.93 & 0.07 \\
\hline The Saudi British Bank & 0.95 & 0.05 \\
\hline Arab National Bank & 0.93 & 0.07 \\
\hline Samba Financial Group & 0.94 & 0.06 \\
\hline Bank Al-Bilad & 0.94 & 0.06 \\
\hline Alinma Bank & 0.71 & 0.29 \\
\hline The National Commercial Bank & 1.00 & 0.00 \\
\hline
\end{tabular}


Chart 2 depicts the probability of shareholder value creation by banks. The sustained improvement in Saudi banks' shareholders' value efficiency was because of supportive factors and regulatory initiatives offered by the central bank (SAMA). High capitalization, profitability and liquidity are the characteristics of the Saudi banking sector, which is the largest segment of the Saudi financial system. The Saudi banks business model continues to focus on the domestic market, limits its external exposure and hence is unexposed to international financial volatility. Saudi banks recorded the high asset growth rates because of the strong economic activities taken place in the recent years. High liquidity and access to low cost funding offers more elasticity to its performance. Liquidity risk is well managed in the Saudi banking sector, as the bank's portfolio largely contains high-quality liquid assets (reserves with SAMA, SAMA bills and Saudi government bonds), closely controlled loan to deposit (LTD) ratio. Moreover, the central banks gives high priority to ensure that banks are fully capable and well positioned to meet cash flow obligations to promote stability. The return measures showed sustained performance around their medium-term averages. The higher profitability levels represent high quality buffer and it signifies banks' improved resistance against any systemic shocks.

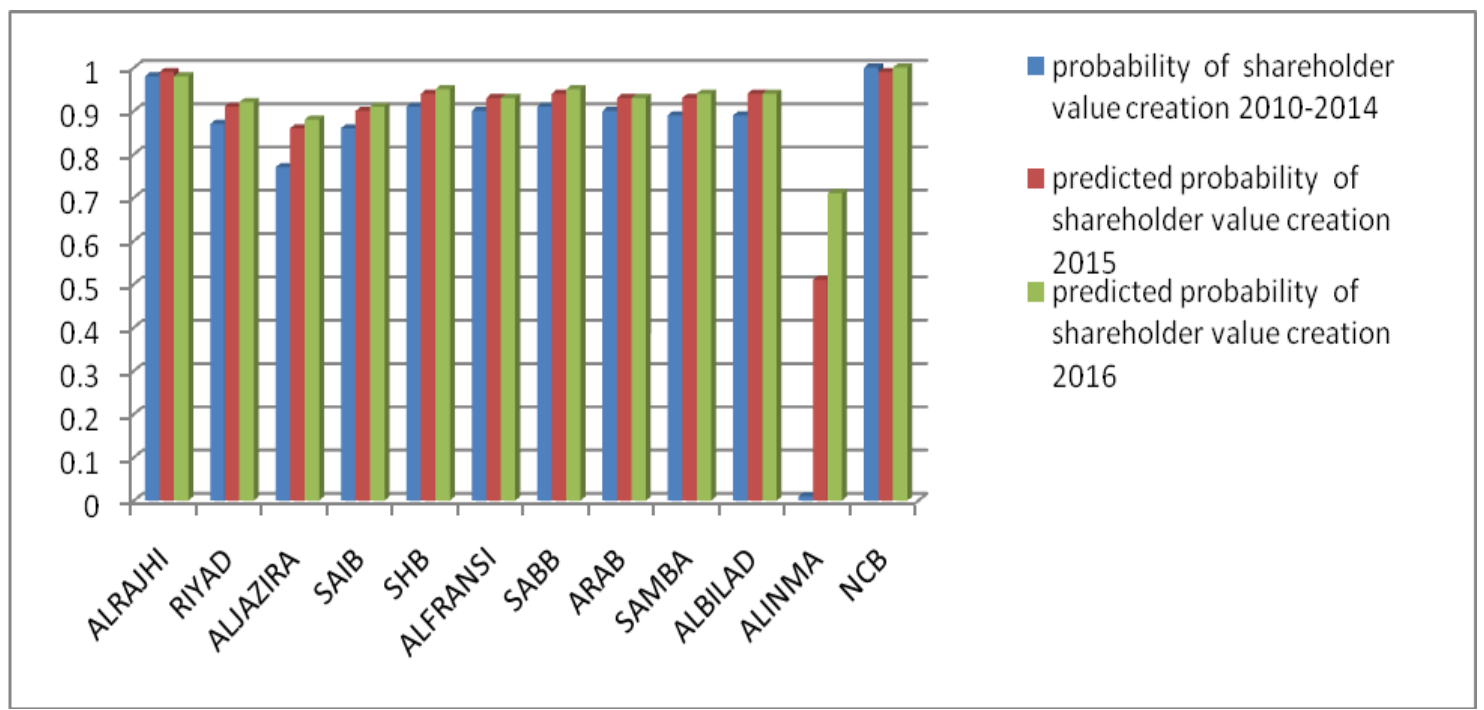

Chart 2. Probability of shareholder value creation by banks

\section{Conclusion}

This paper examines the shareholder efficiency, determinants of market value creation of Saudi Arabia's listed banks and develops a Shareholder Value Index. Evidence indicates that increasing shareholder value is the key to success of Saudi banks. It is found that majority of Saudi banks are being consistent shareholder value creators with a positive Economic Value Addition. Value creation is significantly linked to high Net Operating Profit After Tax and a low cost of capital. The most significant observation is that not all banks with highest capital employed are the highest value creators.

The Market Value Added (MVA) by Saudi banks is highly positive which denotes a positive outlook of the investors on banks' performance. The results of Binary logistic regression analysis reveal that Economic Value Added (EVA) is the best determinant of Market Value Added (MVA) as it explains $42 \%$ of the variation in a bank's ability to create or erode shareholders' wealth. A less degree of correlation between EVA and MVA reveal that more variables/factors could be added to the model to improve the model's predictability. The momentous truth is that the market value of Saudi banks is driven by investors' fancy rather than fundamentals.

The market value is a highly volatile figure that often does not have any mathematical linkage with the internal performance of the banks or a logical one with the fundamentals of the company. Investing purely based on market price changes in a risky investment strategy. Moreover, index generated by various stock exchanges reflects the current market performance of a particular stock, on the other hand fundamental analysis reflects the internal strength of the banks. Given this scenario, the primary objective of the study was to suggest the best value metric and to develop a Shareholder Value Index for Saudi banks. Shareholder value is best measured by metric/s that connects corporate' strategic decisions to economic profit and in turn is correlated to shareholders' wealth. The Shareholder 
Value Index developed in the study will add more information than that provided by fundamental analysts and will enable investors and analysts to group banks based on the probability of shareholder value creation/erosion. The Shareholder Value Index along with the fundamental analysis will enable investors to make a better bet in the capital market. The shareholder value index developed reveal that all Saudi banks are equally competent to create shareholder value, as the probability of wealth creation is high.

Saudi banks' healthier valuations and high degree of resilience because of high capital and liquidity buffers provide the best revelation to the strength of the Saudi economy. The banks' exposure to international markets is low at present but would be highly sought after by foreign investors should the market open further. Banks in Saudi Arabia are equally competent in generating Shareholder Value in the short term, as they are guarded by a sound and stable economic environment. Proactive measures have to be taken to retain the shareholder value efficiency quotient when markets open up for foreign investors.

\section{References}

Acheampong, Y.J., \& Wetzstein, M.E. (2001). A comparative analysis of value added and traditional measures of performance: An efficiency score approach. Social Science Research Network Electronic Paper Collection. FS 01-04.

Al-Faraj et al.. (2006). Evaluating the efficiency of Saudi commercial banks using data envelopment analysis. International Journal of Financial Services Management, 1(4), 466-477.

Arif Almazari, \& Abdelkarim Almumani. (2012). Measuring Profitability Efficiency of the Saudi National Banks. International Journal of Business and Social Science, 3(14), 176.

Beccalli et al., (2006). Efficiency and stock performance in European banking. Journal of Business Finance and Accounting, 33, 245-262.

Biddle G.C., et al.. (1997). Does EVA beat earnings? Evidence on Association with stock returns and firm values. Journal of Accounting and Economics, 24(3), 301-36.

Chu, S.F., \& Lim, G.H. (1998). Share performance and profit efficiency of banks in an oligopolistic market: Evidence from Singapore. Journal of Multinational Financial Management, 8, 155-168.

Eisenbeis et al.. (1999). The informativeness of Stochastic Frontier and Programming Frontier Efficiency Scores: Cost Efficiency and Other Measures of Bank Holding Company Performance. Federal Reserve Bank of Atlanta. Working Paper 99-23.

Fiordelisi, et al.. (2010). The determinants of shareholder value in European Banking. Journal of Banking and Finance, 34, 1189-1200.

Fiordelisi. (2002). Shareholder value and the clash in performance measurement: Are banks special? Centre for banking and finance. Working Paper. University of Wales Bangor,

Fiordelisi. (2007). Shareholder value efficiency in banking. Journal of Banking and Finance, 31, 2151-2171.

Halkos, G.E., \& Salamouris, D.S. (2004). Efficiency Measurement of the Greek Commercial Banks with the Use of Financial Ratios: A Data Envelopment Analysis Approach. Management Accounting Research, 15(2), 201-224.

Khalid Hamad Alturki. (2014). Islamic Banks versus Commercial Banks and Performance: The Context of Saudi Arabia? Global Journal of Management and Business Research, 14(1), 33-44.

Lehen, K., \& Makhija, A.K.M. (1997). EVA, accounting profits and CEO turnover: An empirical examination. Journal of Applied Corporate Finance, 10(2), 90-97.

Munteanu Ancaa, \& Brezeanu Petre. (2012). Do Romanian Banking Institutions Create Shareholder Value?. Emerging Markets Queries in Finance and Business, 3, 144-151.

Nemanja Radic. (2014). Shareholder value creation in Japanese banking. Journal of Banking \& Finance, 52, 199-207.

Noulas, A. (1999). Profitability and Efficiency of the Greek Banks. Journal of the Banking Association of Greece, 19/20, 53-60.

O’Byrne, S.F. (1996). Eva and Market Value. Journal of Applied Corporate Finance, 9(1), 116-125.

Peterson, P. P., \& Peterson D. R. (1996). Company performance and measures of value added. The Research Foundation of the Institute of Chartered Financial Analysts. 
SAMA (2015). Financial stability report - KSA. Global Research-Banking, 26.

Samba. (2015). Saudi Arabia: Baseline Macroeconomic Forecast.

Stewart, G. B. (1990). The Quest for Value: the EVA management guide. Harper Business, New York.

Stewart, G. B. (1991). The Quest for Value: A Guide for Senior Managers. Harper Business, New York.

Uyemura et al.. (1996). EVA® for banks: Value creation, risk management, and profitability measurement. Journal of Applied Corporate Finance, 9(2), 94-113.

\section{Notes}

Note 1. Jadwa Investment Report - Opening the TADAWUL up to Foreign Investors http://www.jadwa.com/en/researchsection/research/market-research

Note 2. Munteanu Ancaa, Brezeanu Petre (2012)

Note 3. Economic Value Added ${ }^{\circledR}$ is a measure of economic profit and product of Stern Stewart. For more insights read: The Quest for Value: Guide for Senior Managers, New York, Harper Business

Note 4. Stewart (1990, p.153) defines market value added. For more insights read: Stewart, G. B. (1991). The Quest for Value: A Guide for Senior Managers, Harper Business, New York.

Note 5. is the financial and investment advisory product of HOLT Value Associates LP and is promoted by the Boston Consulting Group (BCG). More insights refer Shareholder Value Metrics, Booklet 2 of shareholder value management, Boston Consulting Group

Note 6. Controlled for the number of years of establishment, adoption of Islamic banking practices, number of services and nature of the bank

Note 7. To apply binary logistic regression analysis banks have to be grouped into shareholder value creators/eroders but none of the banks in the sample, had negative EVA (shareholder value eroders) for the period of study. Hence, three proxy banks with characteristics of value eroders were included to run the model.

Note 8 . The binary value are given as standard outputs while running BLR (binary logistic regression) in SPSS or it can also be calculated using the logistic equation. 